\title{
The Influence of Socio-Economic Factors on The Productivity of Farmers in The Business of Layers in Blitar Regency
}

\author{
Dwiki Alfikriyadi Lutfi*, Sumarji and Ahsin Daroini \\ Islamic Kadiri University Postgraduate, Kediri, East Java, Indonesia \\ *Corresponding author email: dwiki.alfikri@gmail.com
}

\begin{abstract}
The aim of layer farming is to improve livestock welfare and to increase egg consumption in order to achieve food security programs. Blitar is one of the districts with potential development of layer farming. The objective of this study was to investigate the layer farming in Blitar on the profile of layer chickens, the level of farmer productivity, and the effect of socio-economic factors (the farmers' age, education level, length of farming experience and livestock size) on layer farm labours. The study was conducted using a purposive sampling method, selecting 6 sub-districts as the samples of layer chickens. Respondents were selected by the quota sampling method of 10 farmer in each selected region, collecting 60 farmers as the total sample. The data collected were analyzed descriptively. To identify the social factors on productivity, a classical assumption was tested using multiple linear regression tests. The result showed that the layer farms in Blitar were still managed traditionally. The farmers had a high level of livestock ownership, and they held a heterogeneous socio-economic status. The farmers' age, education background and livestock ownership showed a significant influence, whereas experience in raising livestock did not significantly influence the productivity of layer farmers in Blitar.
\end{abstract}

Keywords: Socio-economic livestock, labour, productivity, layer chickens

Abstrak. Budidaya ayam petelur bertujuan untuk meningkatkan kesejahteraan ternak dan untuk meningkatkan konsumsi telur dalam rangka mencapai program ketahanan pangan. Blitar merupakan salah satu kabupaten yang memiliki potensi pengembangan budidaya ayam petelur. Tujuan penelitian ini adalah untuk mengetahui profil ayam petelur di Blitar, tingkat produktivitas peternak, dan pengaruh faktor sosial ekonomi (umur peternak, tingkat pendidikan, lama bertani dan ukuran ternak) pada pekerja di peternakan ayam petelur. Penelitian dilakukan dengan metode purposive sampling, dengan memilih 6 kecamatan sebagai sampel ayam petelur. Responden dipilih dengan metode quota sampling dari 10 petani di setiap wilayah terpilih, dengan total sampel 60 petani. Data yang terkumpul dianalisis secara deskriptif. Untuk mengidentifikasi faktor sosial terhadap produktivitas dilakukan uji asumsi klasik dengan menggunakan uji regresi linier berganda. Hasil penelitian menunjukkan bahwa peternakan ayam petelur di Blitar masih dikelola secara tradisional. Para petani memiliki tingkat kepemilikan ternak yang tinggi, dan status sosial ekonomi mereka beragam. Umur peternak, latar belakang pendidikan dan kepemilikan ternak menunjukkan pengaruh yang signifikan, sedangkan pengalaman beternak tidak berpengaruh nyata terhadap produktivitas peternak ayam petelur di Blitar.

Kata kunci: sosial ekonomi peternakan, pekerja, produktivitas, ayam petelur

\section{Introduction}

Livestock is a business activity that aims to obtain profits from livestock products, such as laying hens. There are several reasons why laying hens are an agribusiness commodity that cannot be underestimated and targeted by the private sector. The need for eggs as the main foodstuff is a very important factor in the sustainability of laying hens. Many things affect this condition, one of which is socio-economic conditions including mastery of technology, human resources, capabilities, infrastructure and the habits of local farmers (Charles, 2018). From an economic aspect, laying hens is one of the important business fields in terms of labour absorption and the economic cycle. Besides, the existence of animal husbandry is very influential both directly and indirectly for the community. The livestock sector that supports the need for animal protein must be managed optimally to increase farmers' income (Rahmah et al., 2015). Layer farming in Blitar is an important business with an even distribution in almost all districts. Laying chicken farming has an impact on the sustainability of community activities and economy.

Blitar is one of the areas in the Southern Cross East Java region that focus on developing 
an intensive livestock development approach. The areas are grouped to carry out a balanced development of layer farming the development of layer chickens can be carried out evenly, so that in the future it is expected to produce more and supply gr eater national egg needs. Blitar is one of the areas with a potential in developing layer chickens. In general, layer chickens in District are still traditionally carried out without considering the effective and efficient economy; consequently, the farmers' potentials are not fully realized. Even so, the socio-economic aspects greatly affect the productivity of the workforce which will also affect the income of layer chicken farmers (Nurwahyuni et al., 2013).

Socio-economic factors are associated as the initial foundation of farmers that determines their productivity. An increased productivity would enable the farmers to meet high market demand for eggs and to seize the opportunities of collaboration with investors (Pelafu et al., 2018). The socio-economic aspects include the farmer's age, farmers' education background, farming experience, and livestock size. When managed correctly, all these potentials would impact farmers' productivity. Therefore, the socio-economic factors of layer farming needs improvement.

The aim of the study was to identify the correlation or measure the extent of socioeconomic factors in influencing the productivity of farmers in Blitar. The specific objectives were observing the profile of layer chickens in Blitar and investigating the level of farmer productivity as well as the effect of socioeconomic factors (age of farmer, education level, length of livestock raising and number of livestock) on labour productivity in layer chickens in Blitar.

\section{Research Methods}

The study employed a survey method with a sample of 22 sub-districts in Blitar. The study was conducted for three months (1 January - 31 March 2019). The sample was selected by applying a stratified random sampling with the criteria of high, medium and low population (Steel and Torrie, 1980). A purposive sampling method was used to select 6 sub-districts as the samples of layer chickens, namely Kademangan and Ponggok Sub districts (high strata), Wonodadi and Talun Sub districts (medium strata), and Udanawu and Gandusari Districts (low strata). The respondents were selected using a quota sampling method, taking 10 farmers in each selected region, so the total sample was 60 farmers.

Data collected from the questionnaires' responses were analyzed descriptively. To observe the socio-economic influences on work productivity, a classical assumption test was carried out to provide an accurate estimation of the obtained regression equations and to avoid bias and inconsistency. The test consisted of residual normality test, multicollinearity and heteroscedasticity; multiple linear regression analysis and coefficient of determination test. The statistical analysis was performed using (IBM Corp., 2017).

\section{Results and Discussion}

\section{Descriptive Data Analysis \\ General Condition}

Blitar is one of the regencies in the southern part of East Java Province which has 22 subdistricts and 220 villages. Blitar District has an area of $1,588.79 \mathrm{Km} 2$, and it is one of the centers for laying farms. The total population of laying hens spread across 22 districts is $13,513,676$ with an average population of 614,622 hens. The highest population was located in Ponggok District namely, 3,835,238 hens, and the lowest was in Wates District, namely 34,400 hens. Data on the population of laying hens in all districts in Blitar Regency can be seen in Table 1. 
Table 1. Layer population in Blitar

\begin{tabular}{lrlr}
\hline Sub districts & Total & Sub districts & Total \\
\hline Bakung & 334,610 & Selorejo & 41,166 \\
Wonotirto & 38,505 & Doko & 84,960 \\
Panggungrejo & 70,000 & Wlingi & 89,150 \\
Wates & 34,400 & Gandusari & 272,357 \\
Binangun & 83,444 & Garum & 322,186 \\
Sutojayan & 76,237 & Nglegok & $1,001,955$ \\
Kademangan & $2,026,727$ & Sanankulon & 206,349 \\
Kanigoro & 349,602 & Ponggok & $3,835,238$ \\
Talun & 894,450 & Srengat & $1,146,793$ \\
Selopuro & 639,064 & Wonodadi & $1,279,377$ \\
Kesamben & 56,522 & Udanawu & 638,584 \\
\hline Total & & & $\mathbf{1 3 , 5 1 3 , 6 7 6}$ \\
\hline
\end{tabular}

Based on data on the distribution of laying hens in various districts in Blitar Regency, it is also necessary to know the ownership status of layer hens per district. Ownership status can be classified as low if $<200$ birds, medium if between 201-500 birds, and high if $>500$ birds. Based on the data in Table 1, it is known that $68.18 \%$ were districts with low livestock ownership, $22.73 \%$ medium, and $9.09 \%$ high. An overview of the percentage of ownership of laying hens can be seen in Figure 1.

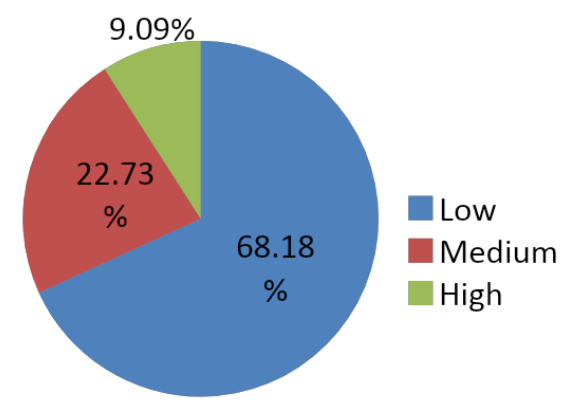

Figure 1. Profile of ownership status of layer hens

\section{Farmer Population}

There is a tendency for men to dominate livestock activities, because it tends to involve physical activities. Women, on the other hand, performed other non-fully physical activities. The distribution of farmers is presented Table 2 . It is shown that farming activities of layer hens were dominated by male farmers $(81.87 \%)$ in which female farmers only contributed $18.13 \%$ in the activities. It emphasizes that livestock activities in almost all sub-districts were dominated by male labours, almost double the female. Overall farmers in each sub-district have a relatively varied number according to the livestock population being raised. The subdistrict which has the highest total farmers is Ponggok Sub district, which amounts to 14,339 people with a ratio of 12,024 males and 2,315 females (a ratio of 84:16 \%). Selopuro sub district had the fewest farmers, namely 3,508 people consisting of 2,828 men and 680 women.

\section{Level of Education}

The data shows that most of the community education is at the primary school level. The social condition of community education is one of the factors that can influence the development of chicken farms in Blitar Regency. The level of education can impact on increasing the consumption of people's awareness of consuming animal protein sources. This can also have an impact on technology uptake and development of profitable and sustainable livestock. The higher the level of community education, the greater the opportunity for the development of layer chicken farms. The data shows that there is a positive trend through an increase in educated people from year to year. Data on the level of public education can be seen in Table 3. 
Table 2. Distribution of layer farmers according to gender

\begin{tabular}{lccccr}
\hline \multirow{2}{*}{ Sub district } & \multirow{2}{*}{ Population } & \multicolumn{2}{c}{ Gender } & Total & $\begin{array}{c}\text { Density } \\
\text { (Person/Km2) }\end{array}$ \\
\cline { 2 - 4 } & & Male & Female & & 229 \\
Bakung & 25,463 & 3,901 & 2,426 & 6,327 & 216 \\
Wonotirto & 35,552 & 4,411 & 1,114 & 5,525 & 346 \\
Panggungrejo & 41,215 & 7,163 & 1,679 & 8,842 & 409 \\
Wates & 28,141 & 4,996 & 900 & 5,896 & 556 \\
Binangun & 42,733 & 7,363 & 1,256 & 8,619 & 1,079 \\
Sutojayan & 47,670 & 4,365 & 735 & 5,100 & 617 \\
Kademangan & 64,960 & 7,308 & 1,548 & 8,856 & 1,370 \\
Kanigoro & 76,108 & 6,591 & 828 & 7,419 & 1,214 \\
Talun & 60,427 & 5,082 & 1,127 & 6,209 & 1,012 \\
Selopuro & 39,759 & 2,828 & 680 & 3,508 & 850 \\
Kesamben & 48,444 & 5,550 & 1,701 & 7,251 & 669 \\
Selorejo & 34,924 & 4,324 & 1,401 & 5,725 & 532 \\
Doko & 37,747 & 5,227 & 751 & 5,978 & 756 \\
Wlingi & 50,168 & 3,774 & 701 & 4,475 & 754 \\
Gandusari & 66,516 & 8,035 & 2,132 & 10,167 & 1,179 \\
Garum & 64,337 & 5,599 & 1,313 & 6,912 & 750 \\
Nglegok & 69,385 & 7,033 & 1,219 & 8,252 & 1,657 \\
Sanankulon & 55,242 & 3,758 & 556 & 4,314 & 966 \\
Ponggok & 100,303 & 12,024 & 2,315 & 14,339 & 1,194 \\
Srengat & 64,441 & 6,460 & 1,350 & 7,810 & 1,158 \\
Wonodadi & 46,744 & 5,710 & 1,295 & 7,005 & 989 \\
Udanawu & 40,514 & 5,106 & 1,001 & 6,107 & $\mathbf{7 1 8}$ \\
\hline Total & $\mathbf{1 , 1 4 0 , 7 9 3}$ & $\mathbf{1 2 6 , 6 0 8}$ & $\mathbf{2 8 , 0 2 8}$ & $\mathbf{1 5 4 , 6 3 6}$ & \\
\hline Source: BPS Blitar (2017) & & & & &
\end{tabular}

Table 3. Level of education

\begin{tabular}{lrrr}
\hline \multicolumn{1}{c}{ Type of school } & \multicolumn{3}{c}{ The number of students } \\
\cline { 2 - 4 } & $\mathbf{2 0 1 1 / 2 0 1 2}$ & $\mathbf{2 0 1 2 / 2 0 1 3}$ & $\mathbf{2 0 1 3 / 2 0 1 4}$ \\
\hline Kindergarten & 28,664 & $\mathbf{2 8 , 6 6 2}$ & 14,839 \\
Grade school & 86,740 & 83,551 & 81,774 \\
Junior high school & 32,253 & 31,536 & 32,438 \\
Senior high school/ vocational school & 16,272 & 18,764 & $\mathbf{1 9 , 6 2 7}$ \\
\hline Total & $\mathbf{1 6 3 , 9 2 9}$ & $\mathbf{1 6 2 , 5 1 3}$ & \\
\hline Average year of education & & $\mathbf{7 . 2 4 - 7 . 2 5}$ & \\
\hline Index level education & & $\mathbf{0 . 5 7 - 0 . 5 9}$ & \\
\hline Source: BPS Blitar (2017) & & &
\end{tabular}

\section{Condition and Potential of Layer chickens}

The farmers' main problem is the declining population of livestock that directly affected the total production. The population decline also resulted in an unsteady income because the BEP of eggs was not reached; consequently, the cash turnover was choked. Another factor was the spread of various infectious diseases that drastically cut off egg production, including Avian Influenza (Al), New Castle Disease (ND), Infectious Bronchitis (IB), Egg Drop Syndrome (EDS) and Body Hepatitis Inclusion (IBH). Data on the comparison between the total livestock and total production in Blitar District from 2012 to 2016 are presented in Table 4.

Table 4 shows that the population and egg production tend to slowly increase each year, but the geographical condition and resources in Blitar potentially meet national eggs demand. The most drastic decline in production occurred in 2014 due to a declining in population from 2013 of $4.28 \%$, although it slightly rose again in 2015 by $1.96 \%$. The rise in the total populations occurred in 2016 by $2.48 \%$. 
Table 4. Comparison between Total Livestock and Total Egg Production

\begin{tabular}{crrrrr}
\hline \multirow{2}{*}{ Comparison } & \multicolumn{5}{c}{ Year } \\
\cline { 2 - 6 } & $\mathbf{2 0 1 2}$ & $\mathbf{2 0 1 3}$ & $\mathbf{2 0 1 4}$ & $\mathbf{2 0 1 5}$ & $\mathbf{2 0 1 6}$ \\
\hline Population (Bird) & $15,336,300$ & $15,336,300$ & $14,679,500$ & $14,973,000$ & $15,170,000$ \\
Production (Ton) & 147,804 & 148,912 & 123,277 & 151,826 & 154,862 \\
\hline
\end{tabular}

Source: BPS Blitar (2017)

\section{Research Result by Analysis \\ Farmers' Age}

The result of direct interviews with farmers in six sub-districts showed that most farmers were in the productive age (aged 15-54) with an average age of 43.55 years. The distribution of farmers based on age groups are presented in Table 5.

Table 5 illustrates that 49 farmers (81.66\%) are in productive age and the rest 11 farmers are above productive age. According to Mardikanto (1993), age is one of the factors that influences the interest in work. As farmers get older, they undergo changes in motivation, interest and skills in breeding.

\section{The Education of Farmer}

Education level is one of the important factors in the management of layer chickens because it determines the quality of soft skills and hard skills. Data on the level of education of farmers in Blitar are presented in Table 6.
Table 6 shows that most layer farmers in Blitar have finished upper secondary level education, indicating the completion of 12-year formal education. Therefore, the average formal education of layer farmers in Blitar is 12 years. The implication is that any increase or improvement of adoption of higher management practices and vice versa, because education enables individuals to keep an open mind to changes to improve their socioeconomic (Bukunmi and Yusuf, 2015). Also, farmers' education background would affect their level of adopting innovation to the livestock business, such as applying technology. Furthermore, the level of education could be a benchmark for the ability to think and react in addressing problems. It was in line with Baliyan and Masuku (2017) that farmers' level of education is often considered effective for decision making and improving skills.

Table 5. Distribution of farmers by age group

\begin{tabular}{ccc}
\hline Age group & Total respondents & Percentage (\%) \\
\hline $0-14$ & 0 & 0 \\
$15-54$ & 49 & 81.66 \\
$>54$ & 11 & 18.34 \\
\hline Total & $\mathbf{6 0}$ & $\mathbf{1 0 0}$ \\
\hline
\end{tabular}

Source: Primary Data Processed, 2019

Table 6. Educational level of farmers in Blitar District

\begin{tabular}{lccc}
\hline \multicolumn{1}{c}{ Education level } & Duration (year) & Total farmers & Percentage (\%) \\
\hline Primary & 6 & 5 & 8.33 \\
Lower Secondary & 9 & 15 & 25 \\
Upper Secondary & 12 & 26 & 43.33 \\
Associate degree & 15 & 0 & 0 \\
Bachelor degree & 16 & 13 & 21.66 \\
Masters degree & 18 & 1 & 1.66 \\
\hline TOTAL & & $\mathbf{6 0}$ & $\mathbf{1 0 0}$ \\
\hline
\end{tabular}

Source: Primary data processed, 2019 


\section{Farming Experience}

Farming experience is the duration or amount of time that has been taken by a farmer in managing his farm business. The data on farming experience of layer farmers in Blitar are presented in Table 7.

Based on Table 7, the farming experience in Blitar varies between 1-10 years, 11-20 years and $>20$ years. Farming experience is closely related to the experience of farmers in running their livestock business as an important factor in carrying out business activities. Damsar and Indrayani (2015) stated that an individual with man experience tends to have better levels of ability and skills. Experience of layer farming is also influenced by external factors that dominantly influence the pattern of maintenance and development of this business activity, either directly or indirectly. One external factor is the influence of technological advances in the field of animal husbandry, including management and maintenance. Table 7 illustrates that farming experience does not affect the productivity of layer farmers in Blitar district.

\section{Livestock Size}

According to Baliyan and Masuku (2017), the criteria for livestock size in this study were divided into three levels, namely low $(0-5,000$ head), medium (5,001-10,000 head) and high (> 10,000 head). The complete data regarding total livestock size are presented in Table 8.

Based on Table 8 , the majority of layer farmers in Blitar District (55\%) have $>10,000$ birds, indicative of high level of ownership. The contributing factors included a good price of egg commodities, technological advances, the availability of good capital and an open market for egg commodities. Related to some issues in layer farming in Blitar districts, some farmers have been able to overcome them in stages and were consistently assisted by various parties, both offices, private sector, and community organizations.

\section{Outpouring of Work for Farmers}

The outpouring of the farmer's work time is the time used by a farmer in running his farm business to achieve the expected results and expressed in male equivalent working hours (JKSP). The details of the outpouring of farmer's work are presented in Table 9.

The results showed that the most timeconsuming activities were feeding and drinking activities, with a total of $342,828 \mathrm{JKSP} /$ year. It is because the activity of feeding and drinking takes about 2 to 3 hours a day, divided into three time periods: morning, afternoon, and evening. Meanwhile, buying - selling administration and financial activities took up the least time, so most farmers did this activity independently (without employees). In Blitar, most of this activity was carried out by old, female employees, while the farmers' wife and children contributed in less vigorous physical activities. It showed that with the existence of layer chickens, the economy of the regency community could be sustained both directly and indirectly.

Table 7. Length of Layer chickens in Blitar District

\begin{tabular}{lcc}
\hline $\begin{array}{c}\text { Length of livestock } \\
\text { raising (year) }\end{array}$ & Number of farmer & Percentage (\%) \\
\hline New $=1-10$ & 31 & 51.67 \\
Medium $=11-20$ & 13 & 21.67 \\
Old $=>20$ & 16 & 26.67 \\
\hline Total & 60 & $\mathbf{1 0 0 . 0 0}$ \\
\hline Source: Primary Data Processed, 2019 & &
\end{tabular}


Table 8. Amount of Livestock size

\begin{tabular}{ccc}
\hline Total ownership & Total (Person) & Percentage (\%) \\
\hline $0-5000$ & 16 & 27 \\
$5001-10000$ & 11 & 18 \\
$>10000$ & 33 & 55 \\
\hline Total & $\mathbf{6 0}$ & $\mathbf{1 0 0}$ \\
\hline
\end{tabular}

Source: Primary data processed, 2019

Table 9. Outpouring of Work for Farmers

\begin{tabular}{lrr}
\hline Type of Activity & Outpouring of work (JKSP/year) & Percentage (\%) \\
\hline Providing feeding and drinking & 342,828 & 49.98 \\
Taking eggs & 113,724 & 16.58 \\
Cleaning the cage & 110,628 & 16.13 \\
Mixed the feed & 48,024 & 7.00 \\
Purchase and finance administration & 34,344 & 5.01 \\
Vaccination and medication & 36,396 & 5.31 \\
\hline Total & $\mathbf{6 8 5 , 9 4 4}$ & $\mathbf{1 0 0 . 0 0}$ \\
\hline Inside the family & $\mathbf{1 2 7 , 5 3 1}$ & $\mathbf{1 8 . 3 5}$ \\
\hline Outside the family & $\mathbf{5 6 7 , 1 0 0}$ & $\mathbf{8 1 . 6 5}$ \\
\hline
\end{tabular}

Source: Primary Data Processed, 2019

\section{Labour Productivity}

Labour productivity is a comparison between the farmers' income and the amount of work done, expressed in male-equivalent working hours (JKSP), and is calculated on a year scale. The average productivity (IDR/year) of layer chickens farming in Blitar District was higher than the minimum wage (UMR). Therefore, layer chicken farming in Blitar has been an effective and efficient business, but the wages for the employees were generally below UMR standard. The data on labour productivity of layer chickens in Blitar are presented in Table 11.

Table 11 illustrates that the level of labour productivity in the business of layer chickens in Blitar District is quite high, as evidenced by the average level of labour productivity by IDR $46,159 / J K S P$. When calculated on 8-hour daily work, the level of productivity per day is IDR 369,272 and total productivity in one month (30 days) is IDR $11,078,160$. The high productivity of the workforce is influenced by various factors, including the total livestock and other sources of business income.

\section{Effect of Socio-Economic Factors on Farmers Productivity \\ Classic Assumption Test \\ Residual Normality Test}

The following is attached to the residual normality curve (Figure 2). The curve showed that the point follows the line and spreads diagonally, so the data can be categorized as normally distributed. The contributing factors include the number of samples that adequately represent the entire population and the distribution of sample areas that are quite heterogeneous and include categories into normal data and are well distributed.

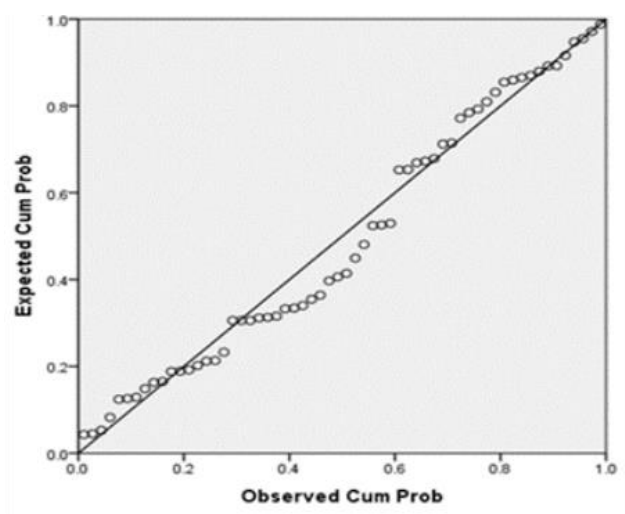

Figure 2. Residual Normality Curve (Source: Primary Data Processed, 2019) 


\section{Multiple Regression Test}

The coefficient table showed that there is no independent variable with a tolerance value under 0.1, hence, there was no correlation between independent variables and no multicollinearity. All VIF values in the coefficients table are below 10 . Accordingly, the data model of the present study has met the requirements of a good regression model because there is no correlation between independent variables (non-multicollinearity). Table 11 shows the result of the test.

Table 10. Distribution of labour productivity

\begin{tabular}{|c|c|c|c|c|c|}
\hline No & Description & Income & Outpouring (hours) & \multicolumn{2}{|c|}{ Labour productivity (IDR/JKSP) } \\
\hline 1 & Maximum & $4,476,000,000$ & 69,241 & & 64,644 \\
\hline 2 & Minimum & $52,240,000$ & 2,373 & & 7,767 \\
\hline Aver & & $567,705,942$ & 11,662 & & 46,159 \\
\hline \multicolumn{6}{|c|}{ Source: Primary Data Processed, 2019} \\
\hline \multirow{2}{*}{\multicolumn{2}{|c|}{ Model }} & \multirow{2}{*}{$\mathbf{t}$} & \multirow{2}{*}{ Sig. } & \multicolumn{2}{|c|}{ Collinearity Statistics } \\
\hline & & & & Tolerance & VIF \\
\hline \multicolumn{2}{|c|}{ (Constant) } & 2.011 & 0.049 & & \\
\hline \multicolumn{2}{|c|}{ Age } & 0.466 & 0.643 & 0.483 & 2.070 \\
\hline \multicolumn{2}{|c|}{ Education } & 0.749 & 0.457 & 0.805 & 1.242 \\
\hline \multicolumn{2}{|c|}{ Length of Livestock Raising } & 0.168 & 0.867 & 0.355 & 2.820 \\
\hline \multicolumn{2}{|c|}{ Number of Livestock } & 0.177 & 0.860 & 0.568 & 1.761 \\
\hline
\end{tabular}

Source: Primary Data Processed, 2019

\section{Heteroscedasticity Test}

The scatter plot graph shows that the points spread randomly above and below the zero on the $Y$ axis. Therefore, the model in this study is a good model because the model includes homoscedasticity of variance from residual values. The following are the attached images of heteroscedasticity test results (Figure 3 ).

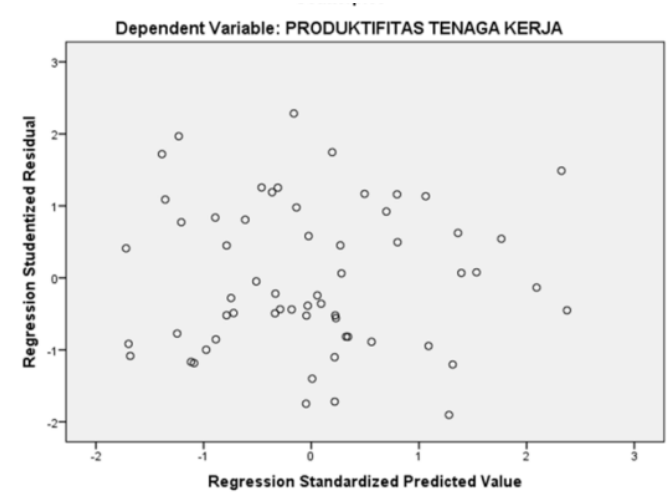

Figure 3. Heteroscedasticity test result (Source: Primary Data Processed, 2019)

\section{Multiple Linear Regression Test}

In this study, multiple linear regression analysis was used to determine the effect of breeders' age factors, farmer education, breeding time and number of livestock on labour productivity to investigate the effect of independent variables on the dependent variable.

The effect age of farmers, education of farmers, farming experience and livestock size can be presented in the following equation: $Y=$ $46,074,713+195,243 \times 1-862,891$ X2 + 90.0747 $\mathrm{X} 3+0.036 \mathrm{X} 4$.

The results of the regression analysis produced a coefficient of determination (R2) 0.40 , indicating that the variation in the dependent variable (labour productivity) was influenced by independent variables (farmer's age, farmer's education, farming experience and number of farmers) by $40 \%$, while the remaining $60 \%$ influenced by other variables not included in the analysis model used.

The result of the $F$ test showed that the calculated $F$ value is 57.8 and $F$ is significant at 67.9. Therefore, $\mathrm{F}$ count $>\mathrm{F}$ table 0.05 : $\mathrm{HO}$ is accepted and $\mathrm{H} 1$ is rejected. It indicated that farmers' age, farmer's education, farming 
experience and livestock size had a simultaneous, significant effect on labour productivity in layer chickens in Blitar, and the

Effect of Independent Variables (X) on Variables $(\mathrm{Y})$ Partially

\section{Age $\left(X_{1}\right)$}

Age factor of farmers (X1) had a significant effect on labour productivity in layer chicken farming in Blitar, with a significance level of 99\% $(\mathrm{P}<0.01)$. The regression coefficient of 195.24 indicates that every one-year increase in age would increase labour productivity by IDR 195.24/JKSP

Based on the results of the study, the average farmers' age is 43.61 years, hence, the productive age. It was closely related to mental conditions that tend to improve with age. Similarly, Mahdalia (2012) stated that the older the person, the more mature and wiser he is. Meanwhile, the physical condition would affect the productivity of livestock businesses, where the farmers' age affected relative ability to work.

In Blitar District this condition is an advantage, because the majority of ages are in productive conditions which will be directly focusing on the business activities. The age composition of the respondent farmers who are mostly productive age is a positive thing because breeders with productive age have stronger physical abilities and are more open in accepting new innovations related to the development of livestock businesses they manage (Rohani and Susanti, 2016).

\section{Education $\left(X_{2}\right)$}

Farmer education variable (X2) had a significant effect on labour productivity. Most levels of education oriented to formal education are related to the implementation of layer farming systems, both in terms of management and technical aspects. The average education of Blitar farmers was high school/upper secondary level, with a duration of 11.98 years. simultaneous independent variables significantly affect labour productivity, with a significance level of 95\% ( $P>0.05)$.

The level of education does not guarantee that a farmer can manage his business optimally, but with education, a farmer can think more openly and has the insights to manage his business. According to Sudrajat and Isyanto (2018), education is an important factor in handling or exercising good management.

Education that can help increase labour productivity directly is the non-formal education oriented to management and technical business activities, such as counseling and training on layer chicken farming maintenance. The results of the study are consistent with Nurwahyuni et al. (2013), that the level of education of farmers shows a significant influence and has a positive relationship with the income of layer farmers.

\section{Farming experience $\left(X_{3}\right)$}

Farming experience factor (X3) significantly affected the labour productivity of layer chickens, with a significance of $99.13 \%(P<0.05)$ and the regression coefficient of 90.07. Hence, every one-year increase in livestock raising would increase labour productivity by IDR 90.07/JKSP.

The result showed the average farming experience was quite long, i.e. 13.93 years, which is included in the category of experienced farmers. The farming experience would positively impact farmer's performance, both managerial and technical maintenance. Similarly, Mahdalia (2012) stated that an experienced individual would exhibit better performance and skills.

Most farmers in Blitar focused on running layer farming as the main livelihood, and some could find alternatives and solutions for their business development, regarding problems, potentials, and challenges. Sarlan and Ahmadi (2017) also stated that farming experience had a positive but not significant effect on the 
productivity of farmers, because respondents were not directly involved in production activities, so they did not significantly affect the farmers' performance.

\section{Livestock size $\left(X_{4}\right)$}

Livestock size (X4) significantly affected labour productivity in layer chickens in Blitar, with a significance of $99 \%(P<0.01)$ and the regression coefficient was 0.36 . Therefore, every increase in livestock size by one chicken would increase labour productivity by IDR 0.36/JKSP.

Livestock size is a determinant of the high and low income of farmers (Risna et al., 2017). Based on the results of the study, most farmers had a relatively high number of livestock, up to 18,358 chicken. Accordingly, farmers could improve productivity by increasing the livestock size.

It shows that the higher the livestock size, the higher the performance. The efforts to achieve the improvement include increasing business capital, improving employee skills, and applying renewable technology to increase the scale of the business being run. Another factor to increase livestock size is the availability of quality seeds accompanied by animal health protection.

\section{Conclusions}

The profile of layer chickens farming in Blitar Regency shows that farmers who carry out traditional farming systems with livestock ownership are among the high categories that have varied socio-economic status. Productivity of layer farmers in Blitar Regency was quite effective and efficient because the value was above the minimum wage (UMR) in Blitar in 2019 (IDR 1,801,409 to IDR 11,078,160 per month). Farmers' age, level of education, and total livestock had a significant effect, while farming experience did not significantly affect the productivity of layer farmers in Blitar.

\section{References}

Baliyan, S. P. and M. B. Masuku. 2017. SocioEconomic Factors as Determinants of Farm Management Skills Among Broiler Poultry Producers in Botswana. International Journal of Agricultural Economics. 2(2):27-34.

BPS Blitar. 2017. Blitar dalam Angka. CV Azka Putra Pratama. Blitar.

Bukunmi, F. R. and H. A. Yusuf. 2015. Analysis of Socio-Economic Factors Influencing Poultry Egg Production among Poultry Farmers in Ondo State, Nigeria. British Journal of Applied Science \& Technology. 10(3):1-7.

Charles, F., A. Suyatno and H. A. Yusra. 2018. Determination Of Agriculture Sector's Superior Commodities In Landak District. Sosial Ekonomi Pertanian Jurnal Agribisnis.8:3.

Damsar and Indrayani. 2015. Pengantar Sosiologi Ekonomi. Prenadamedia Group. Jakarta. Pp:227246.

IBM Corp., 2017. IBM SPSS Statistics for Windows, Armonk, NY: IBM Corp. Available at: https://hadoop.apache.org.

Irmasusanti, S., A. R. Siregar, St. Rohani and Isbandi. 2015. Analisis Faktor Ekonomi, Sosial, Dan Kualitas Pakan Produksi Pabrik Skala Kecil Terhadap Kepuasan Peternak Ayam Ras Petelur Di Kabupaten Sidrap. JITP 3:3.

Mahdalia, A. 2012. Kontribusi Curahan Waktu Kerja Perempuan Terhadap Total Curahan Waktu Kerja pada Usaha Peternakan Sapi Potong di Perdesaan. Jurnal Ecosolum (JES). 2(1):1-5.

Mardikanto, T. 2011. Sistem Penyuluhan Pembangunan Pertanian. UNS Press. Surakarta. Pp:3-30.

Nurwahyuni, E., H. D. Utami and B. Hartono. 2013. Faktor - Faktor Yang Mempengaruhi Kontribusi Usahaternak Ayam Ras Petelur Terhadap Pendapatan Rumahtangga Di Kecamatan Kras Kabupaten Kediri. Jurnal JIIP. (8):03.

Pelafu, F., M. Najoan and F. H. Elly. 2018. Potensi Pengembangan Peternakan Ayam Ras Petelur Di Kabupaten Halmahera Barat. Jurnal Zootek. 38(1):209-219.

Rahmah, U.I.L., 2015. Analisis pendapatan usaha ternak ayam ras pedaging pada pola usaha yang berbeda di Kecamatan Cingambul Kabupaten Majalengka. Agrivet: Jurnal IImu-Ilmu Pertanian dan Peternakan (Journal of Agricultural Sciences and Veteriner), 3(1).

Risna, A., M. Dewi, M. Amin, A. B. L. Ishak. 2017. Changes in The Behavior of Farmers Field School Activities Area Development Assistance Ranch Cattle In Central Sulawesi. Jurnal DOI TP(5)20:228-236. 
Rohani, S. and I. Susanti. 2016. Profil Peternak Ayam Petelur Berdasarkan Skala Usaha Di Kabupaten Sidenreng Rappang, Sulawesi Selatan. Zootek Journal. 26 (1):09-216.

Steel, R.G. and Torrie, J.H., 1980. Principles and Procedures of Statistics McGraw-Hill Book Co. Inc., New York, 481.

Sudrajat and A. Y. Isyanto. 2018. Faktor-Faktor Yang
Sarlan, M. and R. Ahmadi. 2017. Efisiensi Usaha Peternakan Ayam Petelur di Kabupaten Lombok Timur. Jurnal Ilmu dan Industri Perternakan. 3(2): 2-6.

Berpengaruh Terhadap Pendapatan Usaha Ternak Ayam Sentul Di Kabupaten Ciamis. Jurnal Pemikiran Masyarakat Ilmiah Berwawasan Agribisnis. 4(1):70-83. 